HANS SAUER

Munich University

HansSauer@gmx.net

BIRGIT SCHWAN

Munich University

birgit.schwan@googlemail.com

\title{
HEAVEN AND EARTH, GOOD AND BAD, ANSWERED AND SAID: A SURVEY OF ENGLISH BINOMIALS AND MULTINOMIALS (PART I)
}

Keywords: binomials, word-pairs, morphology, etymology, semantics, formulae

\begin{abstract}
Binomials in general and English binomials in particular are a frequent, complex and important linguistic as well as stylistic phenomenon. ${ }^{1}$ Compared to other linguistic phenomena, however, they are a relatively under-researched field. Therefore our aim is to provide a concise survey of English binomials, sketching their structure, function, history and the current state of scholarship, and pointing out possibilities for further research. ${ }^{2}$

In Part I we provide a preliminary definition of binomials (2.), explain the concept of multinomials (3.), discuss the functions of binomials (4.), give a brief review of research (5.), followed by a quick survey of binomials in the history of English (6.), and an example of a dense use of binomials, i.e. where several binomials are used in sequence (7.). Subsequently we discuss some formal features of binomials (8.), especially their basic structure and various variations of it (8.1.), their word classes (8.2.), the conjunctions used (8.3.), additional embellishment and strengthening, especially alliteration and rhyme (8.4.), and other morphological aspects, especially word-formation (8.5.). The second part of this article will be published in the next issue of the journal.
\end{abstract}

1 Stylistics is, of course, an interdisciplinary field: it is part of linguistics as well as of literary studies.

2 Of course we cannot claim completeness - the history of English binomials still remains to be written, and we have only sketched some aspects that can certainly be dealt with in greater detail. 


\section{Sources of the present article}

Most examples come from texts (or selections of texts) which Hans Sauer (and some of his students and colleagues) have analyzed in a number of recent articles; ${ }^{3}$ these are, in rough chronological order: (i) from the $14^{\text {th }}$ century: Geoffrey Chaucer's Canterbury Tales (ca. 1387-1400); (ii) from the $15^{\text {th }}$ century: William Caxton's Ovid (1480); Reginald Pecock's (Peacock's) Donet (ca. 1450), and some anonymous texts, namely: The Historye of the Patriarks; The Wise Book of Philosophy and Astronomy; On Famous Women (a $15^{\text {th }}$ century version of Boccaccio's De claris mulieribus); (iii) from the $17^{\text {th }}$ century: Milton's Samson Agonistes (first published in 1671); (iv) from the $20^{\text {th }}$ and $21^{\text {st }}$ centuries: two recent English translations of the Lotus Sutra, i.e. Watson (1993) and Reeves (2008). Thus there is a concentration on (late) Middle English and Early Modern English - to achieve a more complete picture, Old English texts on the one hand and more Modern English texts on the other hand would have to be taken into account. To assist the reader, we have given some of the Middle English examples in a slightly modernized spelling. ${ }^{5}$

\section{Binomials: a preliminary definition}

A common definition of binomials is that they are pairs of words which belong to the same word-class and are situated at the same syntactic level. ${ }^{6}$ They are connected by a coordinating conjunction (mostly and, or or), and they have some semantic relation, most typically synonymy or antonymy or complementarity. A few examples are lord and master, men and women, heaven and earth, clean and pure, malicious and wicked, to have and to hold, to begin and commence, answered and said, up and down. Some binomials have become fixed and formulaic, but many were created on the spur of the moment.

Unfortunately there is no uniform terminology; the combinations which are discussed here have also been called word-pairs (more specifically repetitive wordpairs or tautologic word-pairs), doublets, doubling of expressions, twin formulae, freezes, etc. ${ }^{7}$ But they are not always repetitive or tautologic, nor are they always formulaic or frozen. Therefore the term binomials is preferred here because it leaves it open whether they are formulaic and have a long history, or whether they have been newly created, and whether they are tautologic or not. The term binomials was apparently coined and first used by Malkiel (1959). ${ }^{8}$

See Sauer (2014); Sauer (forthcoming a, b, c, d); Sauer, Mager (2011). For Chaucer we have mainly used Badura (2016). A few examples have been taken from Malkiel (1959).

4 Boccaccio's De claris mulieribus was actually translated twice, first around 1450 into Late Middle English verse (On Famous Women) and then around 1534-1547 into Early Modern English prose by Henry Parker, Lord Morley; cf. Sauer (forthcoming b). In this article as well as here the focus is on the Middle English verse version.

5 Most of the Middle English words quoted still exist in Modern English.

6 See, e.g. Malkiel (1959: 113), Bhatia (1993: 108).

7 In German Wortpaare, tautologische Wortpaare, etc. 


\section{Multinomials}

Binomials can be extended into multinomials, shading off into lists. ${ }^{9}$ On the whole multinomials are less frequent than binomials. How far multinomials are actually expansions or combinations of binomials and how far they are independent sequences is another question. For example, the quadrinomial (quadruplet) werre or pees or hate or love 'war or peace or hate or love' (Chaucer, Canterbury Tales, Fragment I, 1671) can be regarded as a combination of the binomials 'war and peace' and 'hate or love', and the sequence Gret derth and hunger regnyth and oppressith (The Historye of the Patriarks 75/11f.) can be analyzed as a sequence of the substantival binomial 'dearth and hunger' and the verbal binomial 'reigns and oppresses', and the multinomial his fortune, his bownechef and his myscheff, his manery and his compleccionys obviously contains the (rare) binomial his bownechef and his myscheff 'his good fortune and his bad fortune' (The Wise Book). However, such an easy division of multinomials into groups of binomials is not always possible. Some multinomials apparently have a fixed sequence (e.g. the trinomials Tom, Dick, and Harry, or lock, stock and barrel), but this is not always the case.

In theory there is no limit to the length of multinomials, but probably there is one in practice. Chaucer, for example, has some fairly long multinomials, e.g. one consisting of twelve elements (example 1), and another one consisting of fifteen elements (example 2) - this is the longest multinomial which we have come across so far: ${ }^{10}$

(1) So unkouth and so riche, and wroght so weel,

Of goldsmythrye, of browdynge, and of steel:

The sheeldes brighte, testeres, and trappures,

Gold-hewen helmes, hauberkes, cote-armures;

(Chaucer, Canterbury Tales, Fragment I, 2497-2500) $)^{11}$

(2) Plesaunce and Hope, Desir, Foolhardynesse,

Beautee and Youthe, Bauderie, Richesse,

Charmes and Force, Lesynges, Flaterye,

Despense, Bisynesse, and Jalousye

(Chaucer, Canterbury Tales, Fragment I, 1925-1928) ${ }^{12}$

But long multinomials occasionally also occur in other texts: A sequence of fourteen elements is given in the Lotus Sutra (example 3; transl. Reeves 2008: 55):

(3) monks and nuns, laymen and laywomen, gods, dragons, satyrs, centaurs, asuras, griffings, chimeras, phythons, humans, and non-humans

8 It is a frequent phenomenon in linguistics as well as in other branches of scholarship and science that different terms are applied to the same phenomenon, and conversely, that the same term is applied to different phenomena.

9 On multinomials, cf. also, e.g. Malkiel (1959: 120-121).

10 But see also example (6) in Part II with a multinomial from Pecock that consists of 15 elements.

11 uncouth 'exotic'; browdynge 'embroidery'; testeres 'head-armour for war-horses'; trappures 'horse armour' (Benson 2008: 58).

${ }_{12}$ Plesaunce 'pleasure'; Bauderie 'mirth, jollity'; Lesynges 'falsehood, deceit'; Despense 'expenditures'; Bisynesse 'attentiveness' (Benson 2008: 51). 
The most common multinomials are apparently trinomials (triplets), i.e. sequences consisting of three words, e.g. (a) nouns: unity, rest and peace; wretchedness, sin and cursedness; flesh, hands, and feet; (b) adjectives: an immeasurable, boundless, inconceivable number. See further especially Part II, section 10. Some sequences can be expanded or shortened in order to fit the authors' purposes. Thus the elements of the (antonymous) binomial births and deaths also appear in the quadrinomial birth, old age, sickness, and death, which mirrors a sequence of events, and which also appears in the shortened form as the trinomial old age, sickness and death.

\section{The function of binomials}

Binomials can have several functions, which often overlap. In oral societies they serve as an aid to memory (and often alliterate). In literate societies (at least Western societies) they stand in a stylistic and rhetorical tradition: they help to create a rich, ornate, elevated style (copia verborum), and they also add emphasis. In the early Middle Ages Isidore of Seville (ca. 570-636), who was very influential throughout the Middle Ages and beyond, wrote treatises on synonymy, especially Synonyma (sive lamentatio animae peccatricis) (ed. PL 83, 827-868), and De differentiis verborum (ed. PL 83, 9-70). ${ }^{13}$ In Old English, double glosses provide two (or occasionally even more) synonyms for one Latin lemma (word). In legal and theological language, binomials are also used to make an argument as comprehensive, all-inclusive and as unambiguous as possible ${ }^{14}$ thus the aim to achieve clarity and unequivocality somewhat paradoxically leads to a certain verbosity. Particularly in Middle English a loan-word borrowed recently from French was sometimes explained by a native word or by an earlier loan-word. This is in any case the claim of the so-called translation theory. Although such cases certainly exist, in our experience they are not very frequent (see further Part II, section 9.). Binomials are also a defining element of rhyming slang, which is said to be typical of Cockney, but also of Australian argot. ${ }^{15}$ In rhyming slang, the intended word is replaced by a binomial, the second element of which rhymes with the intended word, e.g. apples and pears = stairs, trouble and strife $=$ wife. Some book titles also consist of binomials, e.g. Pride and Prejudice, or Of Mice and Men. ${ }^{16}$

\section{Research on binomials}

Binomials are interesting for many branches of linguistics, e.g. for phonology (sequence of elements), morphology (especially word-classes), semantics, phraseology

\footnotetext{
PL: Migne, Patrologia Latina.

14 Cf., e.g. Bhatia (1993: 108-110).

15 On rhyming slang see, e.g. Malkiel (1959: 158), and more generally, McArthur (1992, s.v).

16 See Malkiel (1959: 155-156).
} 
(collocations), and etymology. They are also important for the analysis of glosses to Latin texts. In view of this it is striking that comparatively little research on binomials (especially on literary binomials) was done in the $20^{\text {th }}$ century.

European research on binomials began almost exactly two hundred years ago: it was started by Jacob Grimm, who is widely known as a collector of fairy tales (together with his brother Wilhelm), but who was also one of the most important linguists of the $19^{\text {th }}$ century. In an article he tried to show (Grimm 1816) that in Germanic, legal binomials and poetic binomials were related and even had the same origin. In his book on Germanic legal history (Deutsche Rechtsalterthümer $=$ Grimm 1922 [1899]), he provides a collection of legal binomials in various Germanic languages. Grimm did not yet have the term "binomials" (nor any other specific term), and his theory about a common origin of legal and poetic binomials was also criticized and modified by later research. Nevertheless Grimm can be regarded as the originator of two strands of research, namely the use of binomials in legal language and their use in Germanic (including Old English) alliterative poetry. The latest monograph on Old English binomials is apparently Berger (1993). ${ }^{17}$

On the whole, however, there has not been much research on binomials in literary English; especially binomials in Middle English and Modern English literature are a neglected area: for many authors and texts there are not even inventories of their binomials, let alone critical studies. There are less than a handful of twentiethcentury monographs on binomials: apart from Berger (1993) mention should be made of Leisi (1947), Koskenniemi (1968), and Gustafsson (1975).

Leisi (1947) deals with binomials in Caxton's Eneydos, which he calls tautologic word-pairs. ${ }^{18}$ Leisi is also an example of a somewhat negative and self-contradictory attitude towards binomials: He starts by calling them an anomaly in language which is, of course, not true; even if for no other reason, they are simply by far too frequent to be an anomaly. Moreover, Leisi then proceeds to give a very detailed and subtle analysis of the semantic relationship between the two elements of binomials. But Leisi is not alone in his negative attitude towards binomials: Sisam points to the occurrence of binomials in the Old English translation of Alexander's Letter to Aristotle, and he (Sisam 1953: 85) comments: "The style is distinguished from that of Wonders (VE) by tedious doubling of expressions, a practice common in early English translations, but here carried to excess." And as early as 1907 Hecht (1907: 87-88) claimed that Old English translators used binomials ("Wortdoppelungen") because they were unable to render the meaning of a Latin word with one Old English word, and that tautologic binomials show a careless use of language ("gewohnheitsmässige Lässigkeit des Sprachgebrauchs") - that binomials might be a stylistic feature is not a part of his reasoning.

${ }_{17}$ On binomials in Old English, see now also the relevant chapters in Kopaczyk, Sauer (forthcoming).

18 Tautologische Wortpaare. But what Leisi calls tautology apparently refers to synonymy, not to tautology; see further Part II, section 10.1. 
Koskenniemi (1968) gives a (selective) survey of binomials in Old and Early Middle English literature; she calls them repetitive, although they are by no means always repetitive. Gustafsson (1975) is the only $2 \mathrm{O}^{\text {th }}$-century monograph on binomials in Modern English as far as we are aware. She shows that binomials are still frequent in Modern English and provides an analysis, taking morphologic, syntactic and semantic aspects into account. ${ }^{19}$ A ground-breaking article was Malkiel (1959), who investigates especially the sequence of the two words in binomials, and who apparently also coined the term "binomials".

What were the reasons for the relative neglect of binomials in linguistic research, and the negative attitude towards them by scholars such as Hecht (1907), Chambers (1932), Leisi (1947) and Sisam (1953)? One reason may have been changing stylistic ideals. As mentioned above, binomials are characteristic of a rich and rhetorical style, whereas a more modern stylistic ideal is a simple style, and this may also have caused many linguists not to deal with binomials. ${ }^{20}$ This state of affairs is fortunately changing, however, and there has been a revived interest in binomials in recent years; see, e.g. Kopaczyk 2013 (on binomials in Middle Scots), Mollin 2014 (on the sequence of the elements), Sauer 2014 (on binomials in some late Middle English texts), and Kopaczyk, Sauer (forthcoming; a sketch of the historical development). ${ }^{21}$

One cause for the renewed interest in binomials are probably changing currents in linguistic research and linguistic theory. One of the tenets of generative transformational grammar was linguistic creativity (especially syntactic creativity), i.e. the assumption that a competent speaker of a language (in our case of English) can create an infinite number of sentences with the help of a finite number of rules. But generative transformational grammar is no longer as fashionable as it used to be, and in any case it has been modified by recent research, for example by research on phraseology and idioms - this kind of research was, of course, made much easier in recent decades due to the existence of large electronic corpora of English..$^{22}$ It has been shown that a considerable part of language actually consists of prefabricated phrases that are frequently used and re-used - and fixed and formulaic binomials are part of these prefabricated phrases. And whereas rhetoric was also looked down upon for a long time, ${ }^{23}$ there has been a renewed interest in rhetoric in recent decades.

19 Gustafsson occasionally has a somewhat idiosyncratic terminology which can, however, be relatively easily translated into more current terminology.

20 Recently the Plain English Campaign (a commercial enterprise) has been advocating a simple and non-rhetorical style, but we do not know what their attitude towards binomials is.

21 But already Malkiel (1959: 160) stated that binomials "represent one of several features transcending the minimum bounds of linguistic economy and therefore serving the needs of expression much more than those of bare communication," and that if a language were stripped of its binomials, this would be a loss to the language.

22 An early survey of English phraseology written in German (and for a long time the only survey in German) was Gläser (1986), who also includes binomials. A more recent survey of phraseology is, e.g. Allerton et al. (2004), which, however, does not say anything about binomials.

23 Cf., e.g. McArthur (1992, s.v. rhetoric). 


\section{Binomials in the history of English}

Binomials are not confined to English; they occur in many other languages, for example in Latin and in French (see also Part II, section 12.); ${ }^{24}$ Caxton, for example, took over many of his binomials from his French sources. Whether binomials are a linguistic universal is a question that cannot be discussed here, but it surely merits further investigation.

Binomials have certainly been a feature of English from Old English to the present, even though some authors used them more frequently than others. They occur in Old English poetry and prose and in Old English glosses to Latin texts (in the form of double glosses). An Old English author who was particularly fond of binomials was archbishop Wulfstan (Wulfstan the homilist; died 1023), whereas his contemporary, abbot Aelfric (ca. 950 - ca. 1010), did not use them much. Other Old English texts where binomials are frequently employed are, e.g., the Old English translation of the Dialogues by Gregory the Great by Waerferth of Worcester (or Werferth; bishop ca. 872 - 915), the Old English translation of Bede's Historica ecclesiastica gentis Anglorum (= The Old English Bede), and the Old English translation of (the fictitious) Alexander's Letter to Aristotle. ${ }^{25}$

Binomials are also frequent in Middle English poetry and prose, perhaps with a peak in the $15^{\text {th }}$ century. They were employed by well-known poets, authors and translators such as Chaucer and Wycliffe in the $14^{\text {th }}$ century, and by Lydgate, Pecock (Peacock) and Caxton in the $15^{\text {th }}$ century, but they occur also in many anonymous $15^{\text {th }}$-century works such as The Historye of the Patriarks, The Wise Book of Philosophy and Astronomy, On Famous Women, etc. (cf. section 1. above).

The popularity of binomials (and multinomials) continued into the Early Modern English period: for example, Sir Thomas Elyot (ca. 1499-1546) used them in his The Book Called the Governor, and Milton (1608-1674) employed them in his poetry, e.g. in Samson Agonistes. An anonymous Early Modern English text with many binomials is the Calendar of Shepherds. As indicated above, legal texts (including testaments, court proceedings, etc.) are also full of binomials. Many testaments made by Puritans in the late $16^{\text {th }}$ and early $17^{\text {th }}$ centuries show an interesting combination of binomials belonging to legal language and of binomials belonging to religious language. ${ }^{26}$

The use of binomials continues in Modern and Present-Day English (see, e.g. Gustafsson 1975), and their frequency in legal English has been shown, e.g., by Kopaczyk (forthcoming), although the Modern English period is perhaps the most underresearched one as far as binomials, especially binomials in literary use, are concerned. ${ }^{27}$

The history of English binomials still remains to be written, but it will require a lot of additional research.

24 For the use of binomials in other languages, see, e.g. Malkiel (1959: 158-160).

25 On the Old English Dialogues and the Old English Bede see Knappe (1996: 377-379), with further references (to Hart 1901; Kuhn 1947); on the Old English Letter of Alexander to Aristotle see Sisam (1953: [esp.] 85); see further Lemke (2015: 190-197).

26 See the contribution by Ulrich Bach in Kopaczyk, Sauer (forthcoming).

27 But see, e.g. the relevant contributions in Kopaczyk, Sauer (forthcoming); also Sauer (forthcoming d). 


\section{The density and position of binomials}

Not all authors and texts employ binomials, but even those that do, use them in varying density, i.e. clusters of binomials are often preceded or followed by passages with few binomials. In our present context the clusters are, of course, more interesting. One cluster occurs in our example (4), taken from On Famous Women, lines 71-78 (ed. Cowen), a Late Middle English poetic reworking of Boccaccio's De claris mulieribus (in Latin prose), where six lines of a seven-line stanza contain binomials, mostly at the end of the verse: ${ }^{28}$

(4) A boke had made with style full eloquent, A large volume of men famouse and grete In noble dedy, for this cause and intente: That lyke as they bothe in colde and hete Labouryd mightily laude and prayse to gete, To excel odyre in vertu and provess, And theron spent their wyttys and lyvess.

But Chaucer, for example, also has sequences of binomials, as in the Canterbury Tales, Fragment I, 1005-1008 (“The Knight's Tale”), see our example (5):

(5) To ransake in the taas of bodyes dede, Hem for to strepe of harneys and of wede, The pilours diden bisynesse and cure After the bataille and disconfiture. ${ }^{29}$

What the precise function of such clusters is remains to be investigated, but probably there is no single or unified function: ${ }^{30}$ The cluster of binomials in On Famous Women comes near the beginning, where the late Middle English versifier explains his aim and refers to his source, i.e. Boccaccio. The example taken from Chaucer comes from "The Knight's Tale”, where after a battle the bodies of the slain warriors are stripped off their armour and their clothing (as was apparently customary in the Middle Ages). In any case it is striking that in the examples quoted the binomials usually come at the end of a line of verse; this is not only true of the anonymous translator and versifier of On Famous Women, but also of Chaucer, who positions his binomials often at the end of a line. ${ }^{31}$

${ }_{28}$ The Late Middle English poet here refers to the author of his source, namely Boccaccio and his De claris mulieribus.

29 harneys 'armour'; wede 'clothing'; diden bisynesse and cure 'took great pains, worked hard'; disconfiture 'defeat' (Benson 2008: 39).

30 Some suggestions are made by Schenk in Kopaczyk, Sauer (forthcomig); see also section 10.8 below.

31 See also Badura (2016: 6). 


\section{The formal structure of binomials}

8.1. Basic structure, extensions, splits, reductions, exclusions

There is a basic structure of binomials, which can, however, be modified in various ways. $^{32}$

a) Basic: The basic (or simple, or typical, or prototypical) structure of binomials consists of "word + word" ("A + B"), as in the examples given in the preceding section 7 and also in section 2 above; further examples are causes and conditions, leader and teacher, pleasing or ugly, clear and pure, to hear and understand..$^{33}$

b) Extended: Binomials can also be extended in various ways, ${ }^{34}$ for example by adding an article ("the $\mathrm{A}+$ the $\mathrm{B}$ ") or an adjective or a prepositional phrase to nouns, as in the pattern "adjective - noun + adjective - noun", e.g. fine robes and superior garments, or "noun with prepositional phrase + noun with prepositional phrase", as in king of heaven and lord of this world, or nouns with a postmodifying adjective, as in both kings and princes royal.

c) Split: There are also split binomials, especially when one adjective premodifies a noun and the other postmodifies it, as in she was bold in battle and prudent, or a bold theff \& an hardy 'a bold thief and a hardy'.

d) Reduced: Shortened or reduced binomials occur when the connecting conjunction is omitted, e.g. soft, gentle (but also soft and gentle); no peril, no cost; furthermore 'perfect, gentle' from a verry parfit gentil knight (Chaucer, Canterbury Tales, Fragment I, 72).

e) Shortening plus extension: Occasionally there are combinations of shortening plus extension, e.g. profound in wisdom, firm in purpose.

f) Exclusions: A borderline has to be drawn somewhere. Thus we have normally excluded words connected by a subordinating preposition, because prepositions are subordinating and not coordinating, e.g. prison within prison (Milton), or phrases consisting of "verb - object + verb - object", such as settle these doubts and occasion joy, or lost your freedom, entered captivity, because these seem to be too long for binomials - the last two examples contain antonyms, but not all antonyms take the form of binomials. A phrase containing an anaphora such as Thus rit this duc, thus rit this conquerour (Chaucer, Canterbury Tales, Fragment I, 981) also seems too long for a binomial, although it contains an anaphora and although $d u c$ - conquerour on their own could be regarded as a binomial. We have furthermore excluded words (usually loan-words) that are explicitly explained, such as lecherie, pet is golnesse. ${ }^{35}$ But probably there will always be

32 Cf., e.g. Sauer (forthcoming a).

33 These examples have been taken from recent English translations of the Lotus Sutra; see Sauer (forthcoming d).

34 See further, e.g. Malkiel (1959: 134-135).

35 See Jespersen (1972 [1905], \$ 98), who does not really distinguish between such explanatory (relative) clauses and binomials in our sense; see also Part II, section 9. 
borderline cases, and different scholars will draw different lines. ${ }^{36}$ Thus it seems unclear how far word-pairs consisting of names should be included among the binomials; Malkiel (1959: 120) includes, for example, the lexicalized trinomial Tom, Dick, and Harry ('everybody', but derogatory), but it is debatable whether all pairs consisting of names should be included.

\subsection{Word classes: nouns, adjectives, verbs, adverbs}

Usually, i.e. in most texts, binomials consisting of two nouns (substantival binomials) are the largest group (see the examples given so far), followed by binomials consisting of two adjectives and of two verbs - the frequency of adjectives and verbs seems to vary, however. But in the Old English version of Gregory's Dialogues verbal binomials are actually the most frequent group (see Hecht 1907: 88). ${ }^{37}$ Binomials consisting of other word-classes are much rarer, e.g. adverbial binomials such as up and down, far and near, here and there.

Normally, the word-class of the constituents of a binomial is clear, but there are also some ambiguous cases. For example, participles are normally derived from verbs, but sometimes they function as verbal forms and sometimes they function as adjectives. We have usually classified them as adjectives when they are coordinated with clear adjectives, e.g. dignified and virtuous, but as verbs when they are used in clearly verbal constructions as in guarded and kept in mind.

Forms in -ed can be the past or past participle of regular verbs; moreover, they can be extended bahuvrihi adjectives; ${ }^{38}$ in the latter case they are not derived from a corresponding verb, but from a corresponding noun. Flowered in railings and flowered canopies is not derived from a verb ${ }^{\star}$ to flower, but from the noun flower: It means 'having flowers, being decorated with flowers'. Another ambiguous form is the -ing form, which (from Middle English onwards) can express the present participle, the gerund, and the deverbal noun. We have tried to assign examples with the -ing form to the relevant word-class: When they are used together with clear nouns they are listed as nouns, e.g. hunting and venerye (Chaucer, Canterbury Tales, Fragment I, 2308).

36 Thus Malkiel (1959: 129) includes pairs connected with a preposition (side by side), whereas we have excluded them, but like Malkiel (1959: 139-142) we have excluded combinations of words that rather belong to word-formation, e.g. compounds, especially copulative compounds (singer-songwriter, bittersweet) and reduplicative formations (crisscross: reduplication with ablaut).

37 Hecht (1907: 88) says that verbal binomials are "naturally" the most frequent group, but he does not explain why this should be natural.

38 These are adjectives such as one-eyed, three-legged, etc. They are not derived from a corresponding verb (because no corresponding verb exists), but from a phrase expressing a possessive relation, e.g. 'having one eye', 'having three legs'. They are called extended bahuvrihi adjectives because the -ed has been added (which is homonymous with the past participle ending of regular verbs) - in Old English there were simple bahuvrihi adjectives (without the -ed) such as mildheort 'charitable', lit. 'having a mild heart'; the only surviving example in ModE is barefoot 'having bare feet'. 


\subsection{Conjunctions connecting the elements}

Most binomials are connected with and, see the examples given so far. A rarer connection is or, e.g. pleasing or ugly; in earth or sky. Other connectors are still rarer, e.g. ner and ne 'nor', as in by day nor night, or neither ... nor, as in neither herb-craft nor charms.

\subsection{Additional embellishment: alliteration, rhyme}

Additional embellishments of binomials can be alliteration and rhyme. But these are not just embellishments; they also strengthen the cohesion between the elements of a binomial, and - especially in oral societies - make it easier to remember them. But whereas alliteration is relatively frequent, rhyme seems to be very rare. Examples of alliteration are: ${ }^{39}$

a) Nouns: causes and conditions; flowers and fruit; holt and heath (Chaucer); plague and pestilence.

b) Adjectives: fals and fraudulent; stout and strong; sweet and sour.

c) Verbs: escape and eschew; hurt or harm; receive and retain; report and remember, more and magnify (to more is here used as a verb).

Although alliteration was inherited from Old English and ultimately from Germanic, loan-words (from Latin or French) also alliterate in Middle English, as in causes and conditions, flowers and fruit, etc. A sequence of three alliterating binomials is a great slumber and sleep, with a huge and horrible darkness and dread (from The Historye of the Patriarks). An alliterating triplet is 'perfect, profitable and pleasant' (parfite, profitable and plesant).

Rhyming binomials were apparently always much rarer. From the Old English Dialogues of Gregory, Hecht (1907: 88) mentions scylde and gylte 'guilt', and sweetende and woetende 'sweating'. One of the rare Middle English examples is by guile and wile, and a more modern example is wine and dine.

\subsection{Morphology and word-formation}

Binomials consisting of simple (monomorphemic) words seem to be the largest group (see the examples given so far), but there are also binomials where one or both words are complex, i.e. compounds or prefix- or suffix-formations,${ }^{40}$ e.g. neither

39 See further, e.g. Malkiel (1959: 121-125); Markus (2005). For a list of alliterating binomials in the Old English Dialogues of Gregory, see Hecht (1907: 95-96). Oakden (1935: 195-379), has long lists of alliterative phrases in Old and Middle English, but he does not distinguish between binomials in our sense and other alliterative phrases (e.g. sende socour; sowe seed: "verb + object"). Similarly Willert (1911) has a very extensive collection of alliterating phrases, divided into several parts, but whereas some of his examples are binomials in our sense (e.g. arms and armour, old and ugly), others are not (e.g. combinations of "adjective + noun" such as angry eyes, old Adam, or compounds, such as dog days).

40 Cf. also Malkiel (1959: 135-136), although Malkiel refers to the number of morphemes rather than to word-formation in the stricter sense. 
herb-craft nor charms; praise or dispraise; pure and unadulterated; tranquillity and extinction; bravely and virtuously. Suffixation seems to be much more frequent in binomials than compounding or prefixation. Why compounds are relatively rare in binomials is an interesting question. One very tentative answer is that compounds and binomials have opposite functions which are not really compatible: Whereas compounds condense information, binomials expand information. ${ }^{41}$

Examples such as clean and spotless, pure and unadulterated, still and unmoving, yvell \& vngracious 'evil and ungracious' show that synonyms (or complementary pairs) are occasionally created through providing the (prefixal or suffixal) negation of an antonym as the second element. Similarly antonyms are occasionally achieved by negating a positive term, e.g. praise or dispraise. See also the pair superfluous and not praiseworthy (and see Part II, section 10.3 (d)). Youngest and least of age shows that synonymy can also be achieved with syntactic means (i.e. with a phrase).

\section{References}

\section{Editions}

Benson $(2008)=$ Chaucer.

Caxton = Mager W. (ed.). 2016. The Middle English Text of Caxton's Ovid. Books II-III. [= Middle English Texts 53]. Heidelberg.

Chaucer $=$ Benson L.D. (general ed.). 2008. The Riverside Chaucer. $\left[3^{\text {rd }}\right.$ edition, reprinted with a new foreword by Ch. Cannon]. Oxford.

Hecht (2007) see Old English Dialogues of Gregory.

Lotus Sutra = Reeves (2008), Watson (1993).

Milton = Milton J. 2004. The English Poems. [On the cover: The English Poems of John Milton; with introduction and notes by Laurence Lerner]. Ware, Hertfordshire.

Old English Dialogues of Gregory = Hecht H. (ed.). 1900-1907. Bischof Woerferths von Worcester Übersetzung der Dialoge Gregors des Grossen. [vol. 1-2]. [= Bibliothek der angelsächsischen Prosa 5]. Leipzig, Hamburg. [Reprinted in one volume: Darmstadt, 1965. The edition was published in 1900, and the introduction in 1907; in the 1965 reprint the introduction follows the edition].

On Famous Women = Cowen J. (ed.). 2015. The Middle English Translation of Boccaccio's De Mulieribus Claris. [= Middle English Texts 51]. Heidelberg.

Pecock = Hitchcock E.V. (ed.). 1921. The Donet by Reginald Peacock. [= Early English Text Society, Original Series 156; several reprints]. Oxford.

Reeves G. 2008. The Lotus Sutra: A Contemporary Translation of a Buddhist Classic. Boston (MA). The Historye of the Patriarks = Taguchi M. (ed.). 2010. The Historye of the Patriarks. [= Middle English Texts 42]. Heidelberg.

The Wise Book of Philosophy and Astronomy = Griffin C. (ed.). 2013. The Middle English Wise Book of Philosophy and Astronomy. [= Middle English Texts 47]. Heidelberg.

Watson B. 1993. The Lotus Sutra. [Translations from the Asian Classics]. New York.

${ }^{41}$ We have presented our ideas on binomials on several occasions, and we thank all participants in the ensuing discussions for their feedback. As regards the question of compounds and binomials our thanks are especially due to Ursula Lenker, Ulrike Krischke, Christine Elsweiler and others. For interesting additional information, we are also indebted to Somayeh Shafiei. 


\section{Studies and handbooks}

Allerton D.J., Nesselhauf N., Skandera P. (eds.). 2004. Phraseological units: Basic concepts and their application. Basel.

Badura U. 2016. Wortpaare in Chaucers "Canterbury Tales". [Unpublished thesis (Zulassungsarbeit). University of Würzburg].

Berger Ch. 1993. Altenglische Paarformeln und ihre Varianten. [= Münsteraner Monographien zur englischen Literatur 13]. Frankfurt am Main.

Bhatia V.K. 1993. Analysing genre: Language use in professional settings. London.

Chambers R.W. 1932. On the continuity of English prose from Alfred to More and his school. [= Early English Text Society, Original Series 191A]. London.

Gläser R. 1986. Phraseologie der englischen Sprache. Tübingen.

Grimm J. 1816. Von der Poesie im Recht. - Zeitschrift für geschichtliche Rechtswissenschaft 2: 25-99. [Reprinted in his Kleinere Schriften, vol. 6, Berlin 1882: 152-191].

Grimm J. 1922. [1899]. Deutsche Rechtsaltertümer. [vol. 1-2]. Leipzig. [Reprint of $4^{\text {th }}$ edition by A. Heusler \& R. Hübner, Leipzig 1899; $1^{\text {st }}$ edition Leipzig 1828].

Gustafsson M. 1975. Binomial expressions in present-day English: A syntactic and semantic study. [= Annales Universitatis Turkuensis. Ser. B, 136]. Turku.

Hart J.M. 1901. Rhetoric in the Translation of Bede. - An English Miscellany Presented to Dr. Furnivall in Honour of his Seventy-Fifth Birthday. Oxford: 150-154.

Jespersen O. 1972. [1905]. Growth and structure of the English language. [9 $9^{\text {th }}$ edition]. Oxford. [Here quoted from the $9^{\text {th }}$ edition 1972; $1^{\text {st }}$ edition Leipzig 1905].

Knappe G. 1996. Traditionen der klassischen Rhetorik im angelsächsischen England. Heidelberg. Kopaczyk J. (forthcoming). Acts and Statutes: A Comparative Study of Binomials in the $21^{\text {st }}$-century UK and Scottish Legislation.

Kopaczyk J. 2013. The legal language of Scottish burghs: Standardization and lexical bundles (1380-1560). Oxford.

Kopaczyk J., Sauer H. (eds., forthcoming). Binomials in the history of English. Cambridge.

Koskenniemi I. 1968. Repetitive word pairs in Old and Middle English prose. [= Annales Universitatis Turkuensis, Ser. B, 107]. Turku.

Kuhn S.M. 1947. Synonyms in the Old English Bede. - Journal of English and Germanic Philology 46: 168-176.

Leisi E. 1947. Die tautologischen Wortpaare in Caxtons Eneydos: Zur synchronischen Bedeutungs- und Ursachenforschung. Cambridge (MA).

Lemke A. 2015. The Old English translation of Bede's Historia Ecclesiastica Gentis Anglorum in its historical and cultural context. Göttingen.

Malkiel Y. 1959. Studies in irreversible binomials. - Lingua 8: 113-160.

Markus M. 2005. Bed \& board: The role of alliteration in twin formulas of Middle English prose. - Folia Linguistica Historica 26: 71-93.

McArthur T. 1992. The Oxford Companion to the English Language. Oxford.

Mollin S. 2014. The (ir)reversibility of English binomials: Corpus, constraints, developments. Amsterdam.

Oakden J.P. 1935. Alliterative poetry in Middle English. [vol. 2: A Survey of the traditions]. Manchester.

Sauer H. 2014. Twin formulae and more in Late Middle English: The Historye of the Patriarks, Caxton's Ovid, Pecock's Donet. - Bilynsky M. (ed.). Studies in Middle English: Words, forms, senses, and texts. Frankfurt am Main: 25-46.

Sauer H. (forthcoming a). Flexible and formulaic: Binomials and multinomials in the Late Middle English. The Wise Book of Philosophy and Astronomy. 
Sauer H. (forthcoming b). Binomials in the Middle English and Early Modern English versions of Boccaccio's De claris mulieribus.

Sauer H. (forthcoming c). Milton's binomials in Samson Agonistes.

Sauer H. (forthcoming d). The world in two words: Binomials in two English translations of the Lotus Sutra.

Sauer H., Mager W. 2011. Caxton's Ovid, or the Metamorphoses transformed. - Poetica [Tokyo] 75: 125-151.

Sisam K. 1953. Studies in the history of Old English literature. Oxford.

Willert H. 1911. Die alliterierenden Formeln der englischen Sprache. Halle. 